\title{
Sphingosine 1-phosphate regulates inflammation-related genes in human endothelial cells through $\mathrm{S1P}_{1}$ and $\mathrm{S1P}_{3}$
}

\author{
Chi-Iou Lin ${ }^{\text {a }}$, Chiung-Nien Chen ${ }^{\mathrm{c}, \mathrm{d}, \mathrm{e}}$, Po-Wei Lin ${ }^{\mathrm{a}}$, Hsinyu Lee ${ }^{\mathrm{a}, \mathrm{b}, \mathrm{c}, *}$ \\ a Institute of Zoology, National Taiwan University, Taipei 106, Taiwan, ROC \\ ${ }^{\mathrm{b}}$ Department of Life Science, National Taiwan University, Taipei 106, Taiwan, ROC \\ ${ }^{\mathrm{c}}$ Angiogenesis Research Center, National Taiwan University, Taipei 106, Taiwan, ROC \\ d Department of Surgery, National Taiwan University Hospital, Taipei 106, Taiwan, ROC

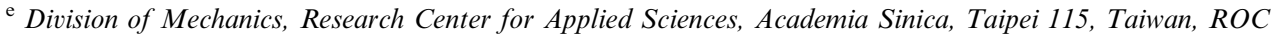

Received 30 January 2007

Available online 20 February 2007

\begin{abstract}
Sphingosine 1-phosphate (S1P) is a bioactive lysophospholipid (LPL) ligand that binds endothelial differentiation gene (Edg) family G-protein-coupled receptors and has been implicated as an important regulator in endothelial cells during inflammation processes. In this study, we attempt to determine which S1P receptors mediating the inflammatory response in human endothelial cells. Our results indicated that introduction of siRNA against $\mathrm{S}_{\mathrm{P}} \mathrm{P}_{1}$ significantly suppressed S1P-induced ICAM-1 mRNA, total protein, and cell surface expressions in human umbilical vein endothelial cells (HUVECs). Moreover, U937 cells adhesion to S1P-treated HUVECs was profoundly reduced by knock-down of $\mathrm{S}_{1} \mathrm{P}_{1}$ in HUVECs. By knock-down of $\mathrm{S}_{1} \mathrm{P}_{1}$ or $\mathrm{S}_{1} \mathrm{P}_{3}$ in HUVECs, S1P-enhanced IL-8, MCP-1 mRNA expression, and THP-1 cell chemotaxis toward S1P-treated HUVEC-conditioned media was profoundly reduced. These results suggested that $\mathrm{S} 1 \mathrm{P}$-induced inflammatory response genes expression is mediated through $\mathrm{S}_{1} \mathrm{P}_{1}$ and $\mathrm{S}_{1} \mathrm{P}_{3}$. Our findings suggest the possible utilization of $\mathrm{S}_{1} \mathrm{P}_{1}$ or $\mathrm{S}_{1} \mathrm{P}_{3}$ as drug targets to treat severe inflammation.
\end{abstract}

(C) 2007 Elsevier Inc. All rights reserved.

Keywords: S1P; $\mathrm{S} 1 \mathrm{P}_{1} ; \mathrm{S} 1 \mathrm{P}_{3}$; Endothelial cells

Sphingosine 1-phosphate (S1P) is a multifunctional bioactive lipid mediator, which binds to cell surface G-proteincoupled receptors (GPCRs) [1,2]. To the present, five S1P receptors have been identified, namely $\mathrm{S}_{\mathrm{P}} \mathrm{P}_{1} / \mathrm{Edg} 1, \mathrm{~S} 1 \mathrm{P}_{2} /$ $\mathrm{Edg} 5, \mathrm{~S}_{1} \mathrm{P}_{3} / \mathrm{Edg} 3, \mathrm{~S}_{1} \mathrm{P}_{4} / \mathrm{Edg} 6$, and $\mathrm{S}_{1} \mathrm{P}_{5} / \mathrm{Edg} 8$, which are members of the Edg (endothelial differentiation gene) receptor family $[1,2]$. Several signaling pathways are activated by Edg receptors via multiple $G$ proteins, including $\mathrm{G}_{\mathrm{q} / 11}, \mathrm{G}_{\mathrm{i} / \mathrm{o}}$, and $\mathrm{G}_{12 / 13}$, which induce diverse physiological functions, including cell differentiation, proliferation, intercellular communication, and wound healing [3].

$\mathrm{S} 1 \mathrm{P}$ receptors transduce a variety of heterologous signal pathways through coupling with multiple $\mathrm{G}$ proteins. $\mathrm{S}_{\mathrm{P}} \mathrm{P}_{1}$

\footnotetext{
* Corresponding author. Address: Department of Life Science, National Taiwan University, Taipei 106, Taiwan, ROC. Fax: +886223636837.

E-mail address: hsinyu@ntu.edu.tw (H. Lee).
}

is predominantly expressed in endothelial cells and exclusively coupled to $\mathrm{Gi}$, which stimulates cell growth, migration, proliferation, and tube formation [4-6]. In contrast, $\mathrm{S}_{1} \mathrm{P}_{2}$ couples strongly to $\mathrm{G}_{12 / 13}$, which negatively activates Rac but positively regulates activation of the small GTPase, RhoA [7]. A recent study reported that S1P downregulates endothelial cell morphogenesis and angiogenesis through activation of $\mathrm{S}_{1} \mathrm{P}_{2}$ [8]. $\mathrm{S}_{1} \mathrm{P}_{3}$ also activates RhoA under some conditions through $\mathrm{G}_{12 / 13}[9]$, and both $\mathrm{S}_{1} \mathrm{P}_{2}$ and $\mathrm{S}_{1} \mathrm{P}_{3}$ have been shown to stimulate phospholipase $\mathrm{C}$ through coupling with $\mathrm{Gq}[10]$. By activation of $\mathrm{S}_{1} \mathrm{P}_{1}$ and $\mathrm{S}_{1} \mathrm{P}_{3}, \mathrm{~S} 1 \mathrm{P}$ can stimulate a $\mathrm{Gi}$ - and $\mathrm{Gq}$-linked intracellular calcium mobilization in various cell types and also enhances endothelial cell migration through activating integrin [11]. It has been suggested that $\mathrm{S}_{1} \mathrm{P}_{4}$ couples to $\mathrm{Gi}$ and $\mathrm{G}_{12 / 13}[12]$. $\mathrm{S} 1 \mathrm{P}_{5}$ couples to Gi but not through $\mathrm{Gq}$ [13]. Our previous studies demonstrated that S1P enhances the expressions of several inflam- 
mation-related genes including ICAM-1, IL-8, and MCP-1 in HUVECs $[14,15]$. These results strongly suggest that $\mathrm{S} 1 \mathrm{P}$ is an important regulator of inflammation processes. However, by which S1P receptors mediating S1P-modulated inflammatory genes expression remains unclear.

Loss-of-function genetic or pharmacologic approaches are required to determine the functions of S1P receptors in vivo [16]. However, $\mathrm{S}_{1} \mathrm{P}_{1}^{-/-}$mice died during mid-gestational stages of embryogenesis [17]. In addition, there are no available specific pharmacologic tools appropriate for inhibiting these receptors. In this report, by utilizing RNAi to suppress S1P receptors gene expressions in HUVECs, we present evidence that S1P-upregulated ICAM-1 mRNA, total protein, cell surface expression in HUVECs, and subsequent cell adhesion of U937 cells with S1P-treated HUVECs are mediated through the activation of $\mathrm{S}_{1} \mathrm{P}_{1}$. In addition, S1P-enhanced IL-8, MCP-1 mRNA expression in HUVECs, and THP-1 cell chemotaxis toward S1P-treated HUVEC-conditioned media are mediated through the activation of both $\mathrm{S}_{1} \mathrm{P}_{1}$ and $\mathrm{S}_{1} \mathrm{P}_{3}$. These results suggest that the binding of S1P to different S1P receptors modulates different inflammatory gene expressions, which contributes to monocyte-endothelium interaction, thus facilitating inflammation processes.

\section{Methods}

Materials. S1P, 1-oleoyl-lysophosphatidic acid (LPA), fatty acid-free bovine serum albumin (FAF-BSA), and lipopolysaccharide (LPS) were purchased from Sigma (St. Louis, MO). The human ICAM-1 antibody (clone M19) and FITC-conjugated mouse anti-human ICAM-1 monoclonal antibody (clone 6.5B5) were purchased from Santa Cruz Biotechnology (Santa Cruz, CA). Horseradish peroxidase-conjugated goat anti-mouse IgG was obtained from Boehringer Mannheim (Indianapolis, IN).

Cell culture. HUVECs were isolated from fresh umbilical cords as described previously [14] and were cultured in M199 medium supplemented with 10\% FBS and 25\% EGM (Cell Applications, San Diego, CA). U937 and THP-1 cells were cultured in RPMI-1640 medium (Gibco) supplemented with $10 \%$ FBS. The cells were maintained under standard cell culture condition at $37{ }^{\circ} \mathrm{C}$ in humidified air with $5 \% \mathrm{CO}_{2}$.

$R T-P C R$ analysis. Total cellular RNA was extracted from HUVECs using the TRIzol reagent (Gibco), and a Superscript kit (Gibco) was used for the reverse-transcription (RT) synthesis of cDNA. Polymerase chain reaction (PCR) amplification was performed with Taq DNA polymerase (Geneaid, Taoyuan, Taiwan) using the set of the primers as follows: 5'GCAAGCTCCCAGTGAAATGCAAAC- $3^{\prime}$ and $5^{\prime}$-TGTCTACTGACC CCAACCCTTGATG-3' (ICAM-1), 5'-ATGACTTCCAAGCTGGCCG TGGCT- $3^{\prime}$ and $5^{\prime}$-TCTCAGCCCTCTTCAAAAACTTCTC- $3^{\prime}$ (IL-8), $5^{\prime}$ TCTCAGTGCAGAGGCTCGCGA- $3^{\prime}$ and $5^{\prime}$-GAGTGAGTGTTCAA GTCTTCG-3' (MCP-1), 5'-ACCACAGTTCATGCCATCAC-3' and 5'TCCACCACCCTGTTGCTGTA-3' (GAPDH), 5'-GACTCTGCTGG CAAATTCAAGCGAC- $3^{\prime}$ and $5^{\prime}$-ACCCTTCCCAGTGCATTGTTCA CAG-3' $\left(\mathrm{S}^{\prime} \mathrm{P}_{1}\right), 5^{\prime}$-CTCTCTACGCCAAGCATTATGTGCT-3' ${ }^{\prime}$ and $5^{\prime}-$ TCAGACCACCGTGTTGCCCTC-3' ${ }^{\prime}\left(\mathrm{S} \mathrm{P}_{2}\right), 5^{\prime}$-CAAAATGAGGCCT TACGACGCCA-3' and ${ }^{\prime}$ '-TCCCATTCTGAAGTGCTGCGTTC- ${ }^{\prime}$ $\left(\mathrm{S}_{1} \mathrm{P}_{3}\right), 5^{\prime}$-AGCCTTCTGCCCCTCTACTC-3' and 5'-GTAGATGATG GGGTTGACCG-3' (S1P 4 ), 5'-GGAGTAGTTCCCGAAGGACC-3' and

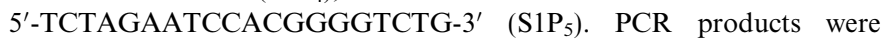
resolved on $2 \%$ agarose gels, stained with ethidium bromide, and then photographed.

Cell transfections. The effective target sequence for scrambled siRNA was: UUCUCCGAACGUGUUCACGUdTdT and ACGUGACACGU

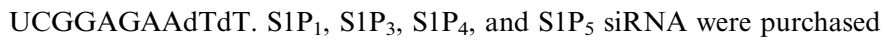

from Santa Cruz Biotechnology. HUVECs were transfected using the optimized protocol for electroporation of HUVECs with the Nucleofector apparatus (Amaxa Biosystems, Cologne, Germany). Cells $\left(1 \times 10^{6}\right)$ were trypsinized, resuspended in $100 \mu \mathrm{l}$ of supplemented HUVEC Nucleofector $^{\mathrm{TM}}$ solution (Amaxa Biosystems), and electroporated in the presence of $7.2 \mu \mathrm{g}$ siRNA.

Western blotting for ICAM-1. Transfected HUVECs cultures were plated in 6-well plates and treated with $5 \mu \mathrm{M}$ of LPA or S1P for $8 \mathrm{~h}$. Treated cells were lysed with RIPA buffer $(150 \mathrm{mM} \mathrm{NaCl}, 1.0 \%$ Nonidet P-40, $0.5 \%$ deoxycholate, $0.1 \%$ SDS, and $50 \mathrm{mM}$ Tris, $\mathrm{pH}$ 8.0) containing a protease inhibitor cocktail (Sigma) and $2 \mathrm{mM} \mathrm{Na}$ vanadate. Equal amounts of cell lysates were separated by $4-10 \%$ SDS-PAGE and electrophoretically transferred to Immobilon ${ }^{\circledR}$ membranes (Millipore, Bedford, MA). The transferred membranes were blocked with blocking buffer (PBS $+0.1 \%$ Tween 20 with $1 \%$ BSA) at room temperature for $1 \mathrm{~h}$. The membranes were immunoblotted with an anti-human ICAM-1 monoclonal antibody for $2 \mathrm{~h}$, washed, and re-incubated for $1 \mathrm{~h}$ with secondary antibody. Membranes were washed and developed using an ECL system (Amersham Biosciences, Piscataway, NJ).

FACscan. Transfected HUVEC cultures were serum starved for $16 \mathrm{~h}$ and incubated with LPA or S1P for $8 \mathrm{~h}$ at $37^{\circ} \mathrm{C}$. Suspensions of $10^{6}$ HUVECs in PBS $(200 \mu 1)$ with $0.1 \%$ fatty acid-free BSA received $2 \mu 1$ of FITC-conjugated human anti-ICAM-1 and were incubated for $30 \mathrm{~min}$ at $4{ }^{\circ} \mathrm{C}$. Antibody binding of HUVECs with and without stimulation was determined by CyFlow ${ }^{\circledR}$ SL (Partec, Münster, Germany) and analyzed by WinMDI version 2.8 software.

In vitro adhesion assay. Transfected HUVECs were cultured in 6-well plates and stimulated with $5 \mu \mathrm{M}$ LPA or S1P for $8 \mathrm{~h}$. After washing with M199 medium, U937 monocytes $\left(1 \mathrm{ml}, 5 \times 10^{6}\right.$ cells $\left./ \mathrm{ml}\right)$ were added to the cultures, and then incubated at $37^{\circ} \mathrm{C}$ for $1 \mathrm{~h}$. Cultures were washed by M199 medium until no visible suspension of U937 cells was observed and then imaged by microscopy. The number of monocytes per culture was counted.

Chemotaxis assay. The trans-well migration of human THP-1 cells toward conditioned media was studied in a 48 -well microchamber (Neuro Probe, Cabin John, MD) as described previously [15]. Cells migrating across the filter onto the lower surface were photographed using light microscopy. Quantification of the migration results was determined by the color intensity of the spots solubilized by solubilization buffer, and the absorbance was determined at $540 \mathrm{~nm}$.

Statistical analysis. Significant differences between control and treatment groups were determined by ANOVA. Each experiment was repeated at least three times. The results are expressed as means \pm SE. A value of $p<0.05$ was considered statistically significant.

\section{Results}

\section{S1P-induced ICAM-1 mRNA expression is mediated} through $S 1 P_{1}$, while IL-8 and MCP-1 mRNA expression is mediated through $S 1 P_{1}$ and $S 1 P_{3}$ in HUVECs

We first determined the S1P receptor expression profiles in HUVECs by RT-PCR (Fig. 1A). Our results indicated that at least $\mathrm{S}_{1} \mathrm{P}_{1}, \mathrm{~S}_{1} \mathrm{P}_{3}, \mathrm{~S}_{1} \mathrm{P}_{4}$, and $\mathrm{S}_{1} \mathrm{P}_{5}$ were expressed in HUVECs. Therefore, we first investigated these S1P receptors' mediation of S1P-induced ICAM-1, IL-8, and MCP-1 mRNA expressions. RNA interference was used to knockdown the expression level of a given S1P receptors. HUVECs were transfected with scrambled- or $\mathrm{S}_{1} \mathrm{P}_{1^{-}}$, $\mathrm{S}_{1} \mathrm{P}_{3^{-}}, \mathrm{S}_{1} \mathrm{P}_{4^{-}}, \mathrm{S}_{1} \mathrm{P}_{5^{-}}$, and $\mathrm{S}_{1} \mathrm{P}_{1}+\mathrm{S}_{1} \mathrm{P}_{3^{-}}$-siRNA duplex. Here, we use LPA, a structural and functional homologous of $\mathrm{S} 1 \mathrm{P}$, as a control in the following experiments. HUVECs transfected with siRNAs specific for each S1P receptors for $48 \mathrm{~h}$ showed significantly decreased each S1P receptors 
A

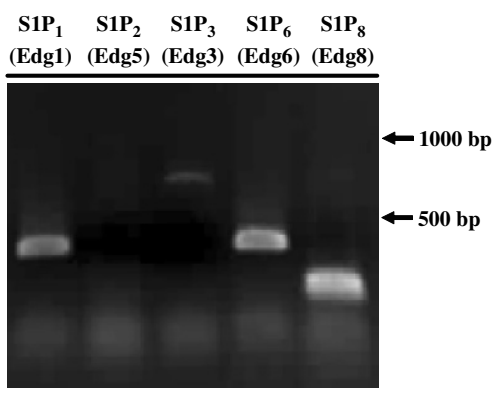

D

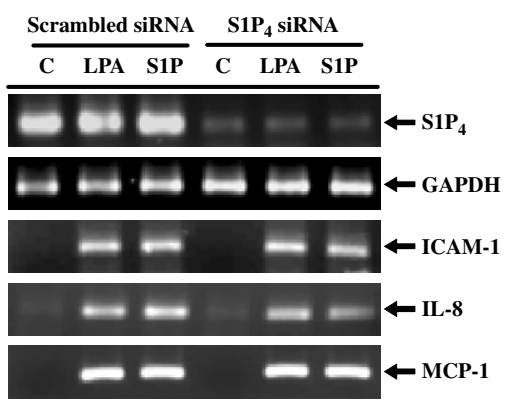

B

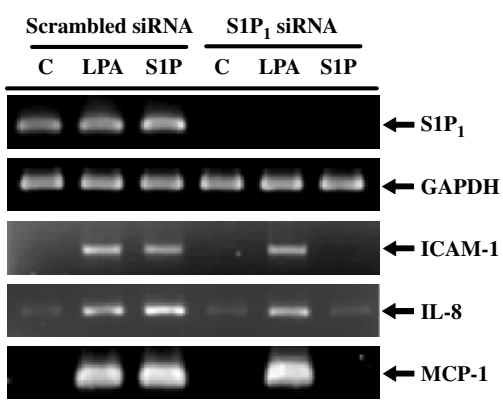

E

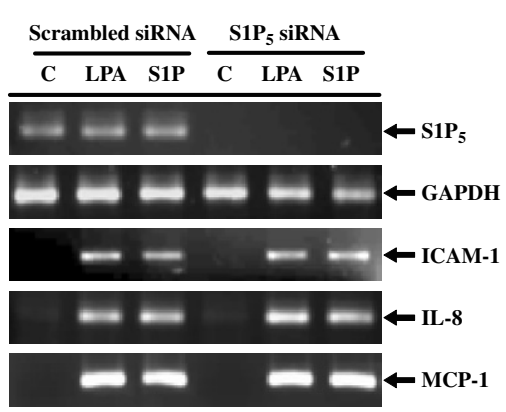

C

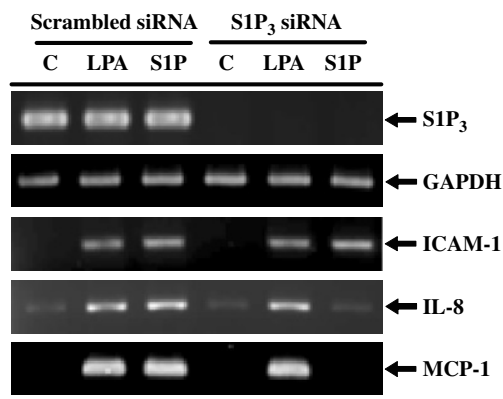

F

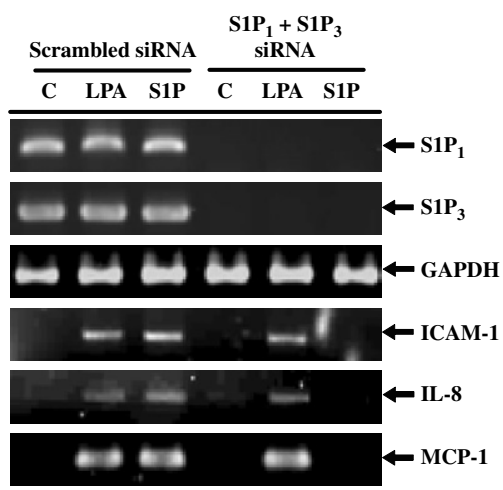

Fig. 1. Effects of S1P receptor siRNAs on ICAM-1, IL-8, and MCP-1 mRNA expressions in HUVECs. (A) cDNA of HUVECs was analyzed by RT-PCR to determine the S1P receptor expression profiles. The expected PCR products were $352,512,701,339$, and 236 bp for $\mathrm{S}_{1} \mathrm{P}_{1}, \mathrm{~S}_{1} \mathrm{P}_{2}, \mathrm{~S}_{1} \mathrm{P}_{3}, \mathrm{~S}_{1} \mathrm{P}_{4}$, and $\mathrm{S}_{1} \mathrm{P}_{5}$. HUVECs were transfected with scrambled or $\mathrm{S}_{1} \mathrm{P}_{1}(\mathrm{~B}), \mathrm{S}_{1} \mathrm{P}_{3}(\mathrm{C}), \mathrm{S}_{\mathrm{P}} \mathrm{P}_{4}(\mathrm{D}), \mathrm{S}_{1} \mathrm{P}_{5}(\mathrm{E}), \mathrm{S}_{\mathrm{P}} \mathrm{P}_{1}+\mathrm{S}_{\mathrm{P}} \mathrm{P}_{3}$ (F) siRNA duplex. Twenty-four hours after transfection, HUVECs were starved and treated with $5 \mu \mathrm{M}$ LPA or S1P for $4 \mathrm{~h}$. ICAM-1, IL-8, and MCP-1 mRNA levels were assessed by RT-PCR. The expression level of $\mathrm{S}_{1} \mathrm{P}_{1}, \mathrm{~S}_{1} \mathrm{P}_{3}, \mathrm{~S}_{1} \mathrm{P}_{4}$ or $\mathrm{S}_{1} \mathrm{P}_{5}$ in each panel was used to evaluate the efficiency of each siRNA. The amount of GAPDH was used as a loading control in each panel. $\mathrm{C}$ represents the untreated control.

mRNA expression in LPA- and S1P-treated and untreated samples (Figs. 1B-F). The expression patterns of GAPDH, which were used as the loading control, did not significantly differ in LPA- or S1P-treated, or untreated samples. Decreases in S1P- but not LPA-induced ICAM-1 mRNA expression were observed in HUVECs transfected with $\mathrm{S}_{1} \mathrm{P}_{1}$ siRNA but not in those transfected with scrambled siRNA (Fig. 1B). Moreover, S1P- but not LPA-induced IL-8 and MCP-1 mRNA expression in HUVECs was significantly suppressed by transfecting with $\mathrm{S}_{1} \mathrm{P}_{1}$ (Fig. 1B) or $\mathrm{S}_{1} \mathrm{P}_{3}$ (Fig. 1C) siRNA. However, the treatment of $\mathrm{S}_{1} \mathrm{P}_{4}$ (Fig. 1D) or $\mathrm{S}_{1} \mathrm{P}_{5}$ (Fig. 1E) showed no suppressive effects. Co-transfection of $\mathrm{S}_{1} \mathrm{P}_{1}$ and $\mathrm{S}_{1} \mathrm{P}_{3}$ siRNAs also showed significant suppressive effects on S1P- but not LPA-enhanced IL-8 and MCP-1 mRNA expression as well as ICAM-1 in HUVECs (Fig. 1F). These results demonstrated that S1Pinduced ICAM-1 mRNA expression is mediated through $\mathrm{S}_{1} \mathrm{P}_{1}$, while IL-8, and MCP-1 mRNA expressions are mediated through $\mathrm{S}_{1} \mathrm{P}_{1}$ and $\mathrm{S}_{1} \mathrm{P}_{3}$ in HUVECs.

\section{S1P-induced ICAM-1 protein expression is mediated through $S_{1} P_{1}$ in HUVECS}

Since S1P's mediation of S1P-induced ICAM-1 mRNA expression was examined, we further investigated if the S1P-elevated mRNA levels of ICAM-1 mediated through $\mathrm{S}_{1} \mathrm{P}_{1}$ were also correlated to protein expression levels. Total ICAM-1 protein levels were detected by Western blotting. Decreases in S1P- but not LPA-induced ICAM-1 total protein expression were observed in HUVECs treated with $\mathrm{S}_{1} \mathrm{P}_{1}$ siRNA (Fig. 2A, left panel) but not those treated with the $\mathrm{S}_{1} \mathrm{P}_{3}$ siRNA (Fig. $2 \mathrm{~B}$, left panel). The expression patterns of $\beta$-actin, which were used as the loading control, did not significantly differ in LPAor S1P-treated, or untreated samples. By FACscan analysis, which detects the antigenic activities of proteins on cell surfaces, we also observed a significant decrease in S1P- but not LPA-induced ICAM-1 cell surface expressions in HUVECs treated with $\mathrm{S}_{1} \mathrm{P}_{1}$ siRNA (Fig. 2A, right panel) and but not those treated with the $\mathrm{S}_{1} \mathrm{P}_{3}$ siRNA (Fig. 2B, right panel). These results indicated that the enhancement effects of S1P on ICAM-1 expression mediated through $\mathrm{S}_{1} \mathrm{P}_{1}$ also occurred with total protein and cell surface expression in HUVECs.

S1P-enhanced adhesive properties of HUVECs toward U937 cells are mediated through $S 1 P_{1}$

In a previous study, we demonstrated that LPLs' enhancement of monocyte adherence to endothelial cells is 

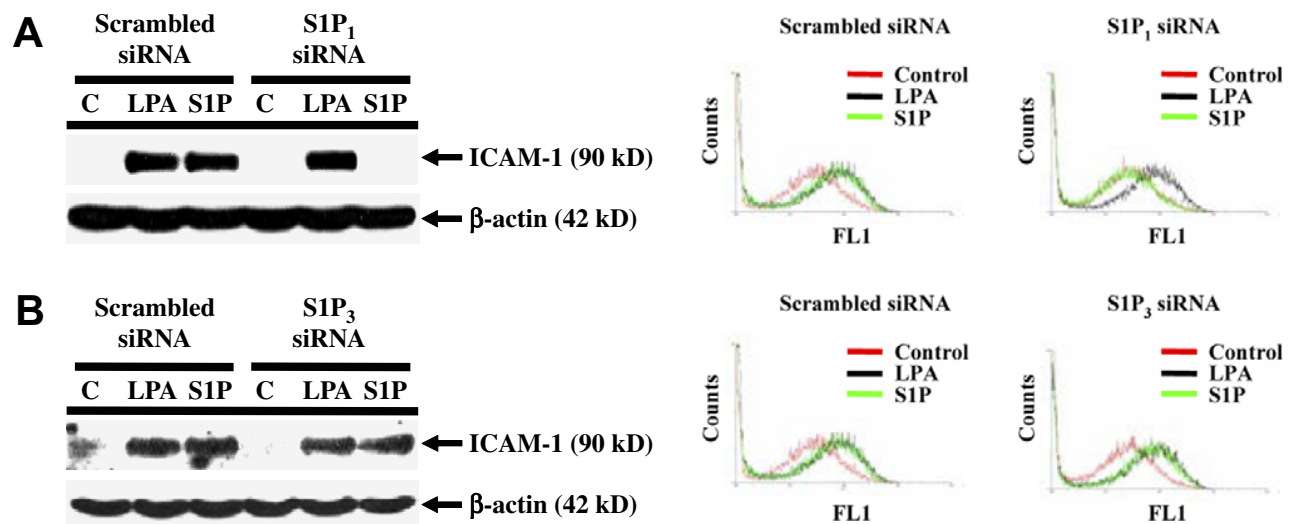
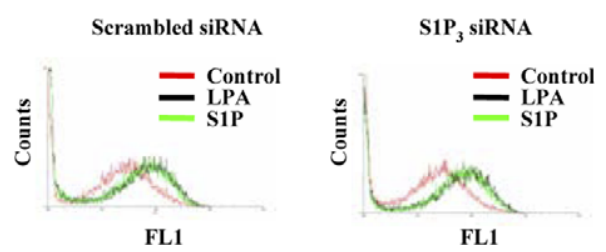

Fig. 2. $\mathrm{S}_{1} \mathrm{P}_{1}$ siRNAs suppressed total and cell surface ICAM-1 protein expressions in HUVECs. HUVECs were transfected with scrambled or $\mathrm{S}_{1} \mathrm{P}_{1}(\mathrm{~A})$,

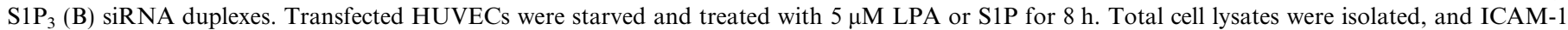
protein expression levels were monitored by Western blotting (left panel) using a human monoclonal anti-ICAM-1 antibody. A human $\beta$-actin antibody was used as the loading control. Treated cells were dissociated by trypsinization and incubated with an FITC-labeled mouse anti-human ICAM-1 monoclonal antibody for $30 \mathrm{~min}$ and analyzed by FACscan (right panel). C represents the untreated control.

A

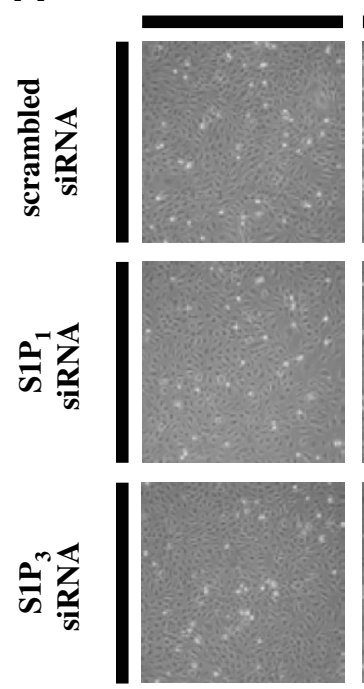

LPA
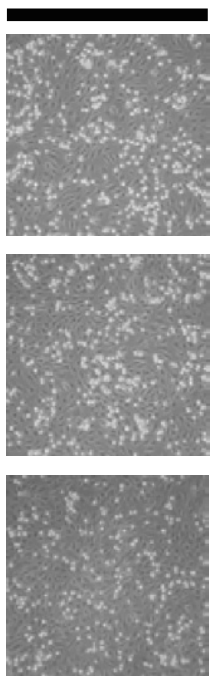

S1P
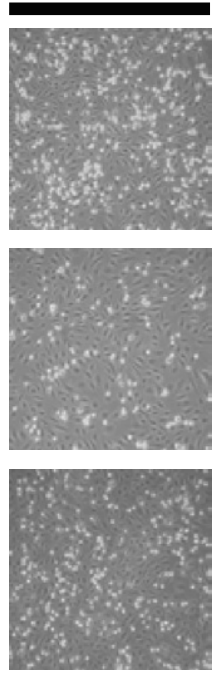

B

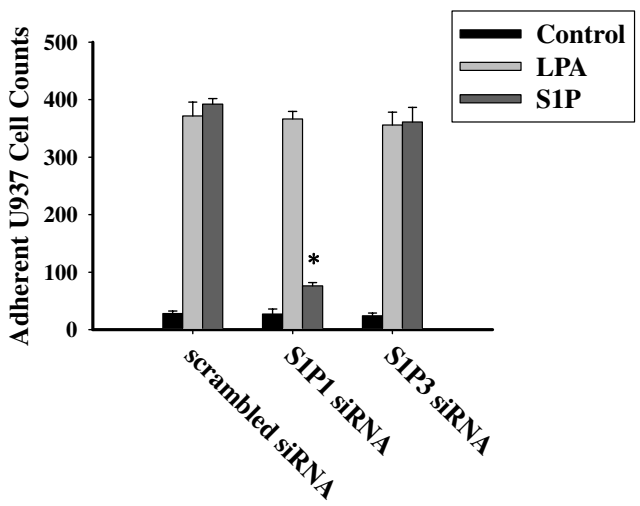

Fig. 3. S1P 1 siRNAs suppressed S1P- but not LPA-enhanced ICAM-1-mediated U937/HUVEC adhesion. (A) HUVECs were transfected with scrambled, $\mathrm{S}_{1} \mathrm{P}_{1}$ or $\mathrm{S}_{1} \mathrm{P}_{3}$ siRNA duplex. Transfected cells were treated with medium, LPA $(5 \mu \mathrm{M})$, or S1P $(5 \mu \mathrm{M})$ for $8 \mathrm{~h}$ and then co-incubated with for $1 \mathrm{~h} 1 \mu \mathrm{g} / \mathrm{ml}$ LPS-stimulated U937 cells. (B) Histograms represent quantification of adherent U937 cell counts $\left({ }^{*} p<0.05\right)$.

mediated through upregulating ICAM-1 expression in endothelial cells [14]. In the present study, we found that the enhancement of ICAM-1 expression by S1P in HUVECs was mediated through $\mathrm{S}_{1} \mathrm{P}_{1}$ (Figs. 1 and 2). We next attempted to investigate if S1P-induced monocytes adhesion toward endothelial cells is mediated through $\mathrm{S}_{1} \mathrm{P}_{1}$. By in vitro adhesion assay, treatment of scrambled siRNA showed no effects on LPS-activated U937 cells adherence to LPA- and S1P-treated HUVECs. However, the treatment of $\mathrm{S}_{1} \mathrm{P}_{1}$ but not $\mathrm{S}_{1} \mathrm{P}_{3}$ siRNA significantly inhibited U937 cells adherence to S1P- but not LPA-treated HUVECs (Fig. 3). These results illustrate that the enhancement effect of S1P on the adhesive property of endothelial cells toward monocytes is only mediated through the activa- tion of $\mathrm{S}_{1} \mathrm{P}_{1}$. Our results suggest that $\mathrm{S}_{1} \mathrm{P}_{1}$ might mediate S1P-induced ICAM-1 expression in HUVECs and subsequently monocytes-endothelium adhesion.

\section{S1P-enhanced chemotactic activity of HUVECs toward U937 cells is mediated through $\mathrm{SIP}_{1}$ and $\mathrm{SIP}_{3}$}

Our previous study indicated that the enhancement effect of S1P on chemotactic activity of endothelial cell is mediated through upregulation of the expressions of IL-8 and MCP-1 [15]. In addition, S1P-enhanced IL-8 and MCP-1 mRNA expressions were mediated through $\mathrm{S}_{1} \mathrm{P}_{1}$ and $\mathrm{S}_{1} \mathrm{P}_{3}$ (Fig. 1). Therefore, we further tested the hypothesis that S1P's enhancement of the chemotactic activity in 


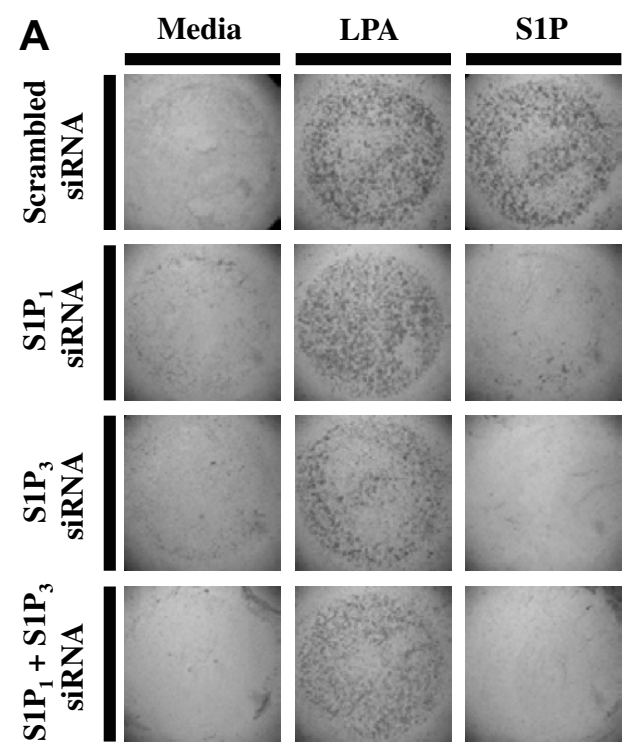

B

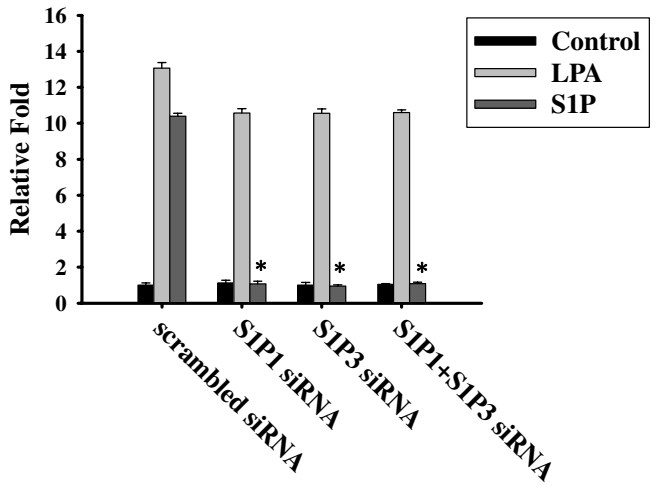

Fig. 4. $\mathrm{S}_{1} \mathrm{P}_{1}$ and $\mathrm{S}_{1} \mathrm{P}_{3}$ siRNAs inhibit the chemotactic activity of conditioned media from S1P- but not LPA-treated HUVECs. (A) HUVECs were transfected with scrambled, $\mathrm{S}_{1} \mathrm{P}_{1}, \mathrm{~S}_{1} \mathrm{P}_{3}$ or $\mathrm{S}_{1} \mathrm{P}_{1}+\mathrm{S}_{1} \mathrm{P}_{3}$ siRNA duplex, followed by medium, LPA $(5 \mu \mathrm{M})$, or S1P $(5 \mu \mathrm{M})$ treatment for $24 \mathrm{~h}$. The chemotactic activity was determined using a 48-well micro chemotaxis chamber. THP-1 cells were added to the upper chambers and allowed to migrate for $4 \mathrm{~h}$ through $8-\mu \mathrm{m}$ porous membranes toward the lower chambers which contained the harvested conditioned media which had been added as indicated. Cells migrated to the lower chambers were fixed, stained, and photographed. (B) Histograms represent quantification results of migrating THP-1 cells $\left({ }^{*} p<0.05\right)$. All data are relative multiples of expression compared to untreated cells.

endothelial cells is mediated through $\mathrm{S}_{1} \mathrm{P}_{1}$ and $\mathrm{S}_{1} \mathrm{P}_{3}$. By a chemotaxis assay, treatment with scrambled siRNA showed no effects on THP-1 cells trans-well migration toward conditioned media of LPA- and S1P-treated HUVECs. However, conditioned media collected from $\mathrm{S}_{1} \mathrm{P}_{1}, \mathrm{~S}_{1} \mathrm{P}_{3}$ or $\mathrm{S}_{1} \mathrm{P}_{1}+\mathrm{S}_{1} \mathrm{P}_{3}$ siRNA-transfected HUVECs significantly inhibited S1P- but not LPA-enhanced THP-1 cell trans-well migration (Fig. 4). These results imply that the enhancement effects of S1P on the chemotactic activity of endothelial cell are mediated through $\mathrm{S}_{1} \mathrm{P}_{1}$ and $\mathrm{S}_{1} \mathrm{P}_{3}$ activation. Our results suggest that $\mathrm{S}_{1} \mathrm{P}_{1}$ and $\mathrm{S} 1 \mathrm{P}_{3}$ might mediate S1P-induced IL-8 and MCP-1 expression in HUVECs and subsequently monocytes chemoattracting toward endothelium.

\section{Discussion}

By RT-PCR, we found that not all S1P receptors are expressed in HUVECs. $\mathrm{S}_{1} \mathrm{P}_{2}$ is not expressed in HUVECs, which is consistent with previous reports [3]. A previous study reported that long-term silencing of $\mathrm{S}_{1} \mathrm{P}_{1}$ profoundly alters various gene expressions in a cultured human $\mathrm{S}_{1} \mathrm{P}_{1^{-}}$ knock-down angiosarcoma cell line [18]. In the present study, we further confirmed that $\mathrm{S}_{1} \mathrm{P}_{1}$ regulates inflammation-related gene expressions of ICAM-1, IL-8, and MCP-1 in HUVECs (Fig. 1). Recent evidence indicates that $\mathrm{S}_{1} \mathrm{P}_{1}$ and $\mathrm{S}_{1} \mathrm{P}_{3}$ are the most abundant $\mathrm{S} 1 \mathrm{P}$ receptors in HUVECs $[5,6,19]$. Through activation of $\mathrm{S}_{1} \mathrm{P}_{1}$ and $\mathrm{S}_{1} \mathrm{P}_{3}, \mathrm{~S} 1 \mathrm{P}$ induces endothelial cell migration, and these effects are exclusively Gi-dependent [6,19]. Our previous study demonstrated that S1P-induced ICAM-1 expression in HUVECs is Gidependent and independent of Rho [14], whereas IL-8 and MCP-1 expression are both Gi- and Rho-dependent [15]. These observations are consistent with the facts that $\mathrm{S}_{1} \mathrm{P}_{1}$ exclusively couples to $\mathrm{Gi}[4]$ and $\mathrm{S}_{1} \mathrm{P}_{3}$ could activate $\mathrm{G}_{12 / 13}$-Rho pathway [7]. Through the in vitro evidences presented in this report, we suggest that $\mathrm{S}_{1} \mathrm{P}_{1}$ expressed on endothelial cells plays a key role on regulating monocytes adhesion and chemotaxis to endothelial cells, whereas $\mathrm{S}_{1} \mathrm{P}_{3}$ is only essential for endothelial cells to chemoattract monocytes.

It has been reported that $\mathrm{S}_{1} \mathrm{P}_{1}$ might mediate both stimulatory and inhibitory signals for monocyte-endothelial cell interaction [20]. In our study, S1P $(5 \mu \mathrm{M})$ enhances monocytes adhesion to endothelial cells through upregulating the ICAM-1 expression of endothelial cells [14], and these enhancement effects are mediated through activation of $\mathrm{S}_{1} \mathrm{P}_{1}$. However, recent study also reported that low concentration of $\mathrm{S} 1 \mathrm{P}(0.1 \mu \mathrm{M})$ prevents monocytes adhesion to endothelial cells extracted from diabetic NOD mice through activation of $\mathrm{S}_{1} \mathrm{P}_{1}$, and these suppressive effects are due to decrease of ICAM-1 and VCAM-1 expression [21]. In addition, S1P $(0.1 \mu \mathrm{M})$ also prevented TNF- $\alpha$-induced monocyte adhesion to endothelial cells through $\mathrm{S}_{1} \mathrm{P}_{1}$ [22]. Moreover, moderate concentration $(1 \mu \mathrm{M})$ of HDL-composed S1P positively or negatively regulates ICAM-1 expression in endothelial cells and monocytes-endothelium adhesion through $\mathrm{S}_{1} \mathrm{P}_{1}$ and $\mathrm{S}_{1} \mathrm{P}_{3}$, respectively $[23,24]$. These observations suggest that upon binding with $\mathrm{S}_{1} \mathrm{P}_{1}$, different concentrations of S1P may play diverse roles in mediating monocyte-endothelium adhesion.

Accumulating evidence indicates that $\mathrm{S}_{1} \mathrm{P}_{1}$ is important for S1P's regulation of various cellular behaviors in endothelial cells such as cell migration [6], tube formation 
[16,17], and cell adherent junction morphogenesis [5], which suggests that the activation of $\mathrm{S}_{1} \mathrm{P}_{1}$ is essential for S1P's promotion of angiogenesis $[17,25]$. Our findings further suggest that $\mathrm{S}_{1} \mathrm{P}_{1}$ and $\mathrm{S}_{1} \mathrm{P}_{3}$ are required for S1P's upregulation of the adhesive property for the tight adherence with monocytes and the chemotactic activity of endothelial cells, which play important roles in S1P-regulated inflammation processes. Recent studies proposed that S1P might be a target for establishing a therapeutic strategy for controlling cardiovascular disease [26]. Moreover, $\mathrm{S} \mathrm{P}_{1}$ and $\mathrm{S}_{1} \mathrm{P}_{3}$ are key targets in new drug development for regulating angiogenesis [27]. Herein, our findings were focused on modulating the functions of $\mathrm{S}_{1} \mathrm{P}_{1}$ and $\mathrm{S}_{1} \mathrm{P}_{3}$, which may further offer a novel perspective for anti-inflammation drug discoveries.

In summary, our results clearly indicate that S1P increases ICAM-1 mRNA, total protein, and cell surface expression in HUVECs are mediated through the activation of $\mathrm{S}_{1} \mathrm{P}_{1}$. In addition, S1P increases IL-8 and MCP-1 mRNA expression in HUVECs is mediated through $\mathrm{S}_{1} \mathrm{P}_{1}$ and $\mathrm{S}_{1} \mathrm{P}_{3}$. Moreover, $\mathrm{S}_{1} \mathrm{P}_{1}$ expressed on endothelial cells mediates the positive regulation on monocytes adhesion and chemotaxis toward endothelium, whereas $\mathrm{S}_{1} \mathrm{P}_{3}$ is only critical for endothelial cells chemoattract monocytes. Our findings suggest that $\mathrm{S}_{1} \mathrm{P}_{1}$ and $\mathrm{S}_{1} \mathrm{P}_{3}$ might be essential receptors for S1P on modulating monocyte-endothelial cell interactions, which provides valid information necessary for developing new therapeutic drugs against the inflammation process and atherosclerosis formation.

\section{Acknowledgments}

We thank Dr. S.M. Hsieh at National Taiwan University Hospital provided umbilical cords for endothelial cell preparation. This work was supported by Grants 95-2311-B-002018-MY2 (H. Lee), and NSC 95-2314-B002-151 (C. Chen) from the National Science Council.

\section{References}

[1] S. An, E.J. Goetzl, H. Lee, Signaling mechanisms and molecular characteristics of $\mathrm{G}$ protein-coupled receptors for lysophosphatidic acid and sphingosine 1-phosphate, J. Cell. Biochem. 30-31 (1998) 147-157.

[2] W.H. Moolenaar, Bioactive lysophospholipids and their G proteincoupled receptors, Exp. Cell Res. 253 (1999) 230-238.

[3] H. Lee, E.J. Goetzl, S. An, Lysophosphatidic acid and sphingosine 1-phosphate stimulate endothelial cell wound healing, Am. J. Physiol. Cell Physiol. 278 (2000) C612-C618.

[4] H. Okamoto, N. Takuwa, K. Gonda, H. Okazaki, K. Chang, Y. Yatomi, H. Shigematsu, Y. Takuwa, EDG1 is a functional sphingosine-1-phosphate receptor that is linked via a Gi/o to multiple signaling pathways, including phospholipase $\mathrm{C}$ activation, $\mathrm{Ca} 2+$ mobilization, Ras-mitogen-activated protein kinase activation, and adenylate cyclase inhibition, J. Biol. Chem. 273 (1998) 27104 27110 .

[5] M.J. Lee, S. Thangada, K.P. Claffey, N. Ancellin, C.H. Liu, M. Kluk, M. Volpi, R.I. Sha'afi, T. Hla, Vascular endothelial cell adherens junction assembly and morphogenesis induced by sphingosine-1phosphate, Cell 99 (1999) 301-312.
[6] J.H. Paik, S. Chae, M.J. Lee, S. Thangada, T. Hla, Sphingosine 1phosphate- induced endothelial cell migration requires the expression of EDG-1 and EDG-3 receptors and Rho-dependent activation of alpha vbeta3- and beta 1-containing integrins, J. Biol. Chem. 276 (2001) 11830-11837.

[7] N. Sugimoto, N. Takuwa, H. Okamoto, S. Sakurada, Y. Takuwa, Inhibitory and stimulatory regulation of Rac and cell motility by the $\mathrm{G}_{12 / 13}$-Rho and $\mathrm{Gi}$ pathways integrated downstream of a single $\mathrm{G}$ protein-coupled sphingosine 1-phosphate receptor isoform, Mol. Cell. Biol. 23 (2003) 1534-1545.

[8] I. Inoki, N. Takuwa, N. Sugimoto, K. Yoshioka, S. Takata, S. Kaneko, Y. Takuwa, Negative regulation of endothelial morphogenesis and angiogenesis by $\mathrm{S}_{1} \mathrm{P}_{2}$ receptor, Biochem. Biophys. Res. Commun. 346 (2006) 293-300.

[9] I. Ishii, X. Ye, B. Friedman, S. Kawamura, J.J. Contos, M.A. Kingsbury, A.H. Yang, G. Zhang, J.H. Brown, J. Chun, Marked perinatal lethality and cellular signaling deficits in mice null for the two sphingosine 1-phosphate (S1P) receptors, S1P(2)/LP(B2)/EDG-5 and S1P(3)/LP(B3)/EDG-3, J. Biol. Chem. 277 (2002) 25152-25159.

[10] T. Hla, M.J. Lee, N. Ancellin, J.H. Paik, M.J. Kluk, Lysophospholipids-receptor revelations, Science 294 (2001) 1875-1878.

[11] S. An, T. Bleu, Y. Zheng, Transduction of intracellular calcium signals through $G$ protein-mediated activation of phospholipase $C$ by recombinant sphingosine 1-phosphate receptors, Mol. Pharmacol. 55 (1999) 787-794.

[12] M.H. Graler, R. Grosse, A. Kusch, E. Kremmer, T. Gudermann, M. Lipp, The sphingosine 1-phosphate receptor S1P4 regulates cell shape and motility via coupling to Gi and G12/13, J. Cell. Biochem. 89 (2003) 507-519.

[13] D.S. Im, C.E. Heise, N. Ancellin, B.F. O'Dowd, G.J. Shei, R.P. Heavens, M.R. Rigby, T. Hla, S. Mandala, G. McAllister, S.R. George, K.R. Lynch, Characterization of a novel sphingosine 1phosphate receptor, Edg-8, J. Biol. Chem. 275 (2000) 14281-14286.

[14] H. Lee, C.I. Lin, J.J. Liao, Y.W. Lee, H.Y. Yang, C.Y. Lee, H.Y. Hsu, H.L. Wu, Lysophospholipids increase ICAM-1 expression in HUVEC through a Gi- and NF-kappaB-dependent mechanism, Am. J. Physiol. Cell Physiol. 287 (2004) C1657-C1666.

[15] C.I. Lin, C.N. Chen, J.H. Chen, H. Lee, Lysophospholipids increase IL-8 and MCP-1 expressions in human umbilical cord vein endothelial cells through an IL-1-dependent mechanism, J. Cell. Biochem. 99 (2006) 1216-1232.

[16] S.S. Chae, J.H. Paik, H. Furneaux, T. Hla, Requirement for sphingosine 1-phosphate receptor-1 in tumor angiogenesis demonstrated by in vivo RNA interference, J. Clin. Invest. 114 (2004) 1082 1089.

[17] Y. Liu, R. Wada, T. Yamashita, Y. Mi, C.X. Deng, J.P. Hobson, H.M. Rosenfeldt, V.E. Nava, S.S. Chae, M.J. Lee, C.H. Liu, T. Hla, S. Spiegel, R.L. Proia, Edg-1, the G protein-coupled receptor for sphingosine-1-phosphate, is essential for vascular maturation, J. Clin. Invest. 106 (2000) 951-961.

[18] V. Krump-Konvalinkova, S. Yasuda, T. Rubic, N. Makarova, J. Mages, W. Erl, C. Vosseler, C.J. Kirkpatrick, G. Tigyi, W. Siess, Stable knock-down of the sphingosine 1-phosphate receptor S1P1 influences multiple functions of human endothelial cells, Arterioscler. Thromb. Vasc. Biol. 25 (2005) 546-552.

[19] T. Kimura, T. Watanabe, K. Sato, J. Kon, H. Tomura, K. Tamama, A. Kuwabara, T. Kanda, I. Kobayashi, H. Ohta, M. Ui, F. Okajima, Sphingosine 1-phosphate stimulates proliferation and migration of human endothelial cells possibly through the lipid receptors, Edg-1 and Edg-3, Biochem. J. 348 (2000) 71-76.

[20] T. Kimura, H. Tomura, C. Mogi, A. Kuwabara, M. Ishiwara, K. Shibasawa, K. Sato, S. Ohwada, D.S. Im, H. Kurose, T. Ishizuka, M. Murakami, F. Okajima, Sphingosine 1-phosphate receptors mediate stimulatory and inhibitory signalings for expression of adhesion molecules in endothelial cells, Cell. Signal. 18 (2006) 841-850.

[21] A.M. Whetzel, D.T. Bolick, S. Srinivasan, T.L. Macdonald, M.A. Morris, K. Ley, C.C. Hedrick, Sphingosine-1 phosphate prevents monocyte/endothelial interactions in type 1 diabetic NOD mice 
through activation of the S1P1 receptor, Circ. Res. 99 (2006) 731739.

[22] D.T. Bolick, S. Srinivasan, K.W. Kim, M.E. Hatley, J.J. Clemens, A. Whetzel, N. Ferger, T.L. Macdonald, M.D. Davis, P.S. Tsao, K.R. Lynch, C.C. Hedrick, Sphingosine-1-phosphate prevents tumor necrosis factor-\{alpha\}-mediated monocyte adhesion to aortic endothelium in mice, Arterioscler. Thromb. Vasc. Biol. 25 (2005) 976-981.

[23] T. Kimura, K. Sato, E. Malchinkhuu, H. Tomura, K. Tamama, A. Kuwabara, M. Murakami, F. Okajima, High-density lipoprotein stimulates endothelial cell migration and survival through sphingosine 1-phosphate and its receptors, Arterioscler. Thromb. Vasc. Biol. 23 (2003) 1283-1288.

[24] T. Kimura, H. Tomura, C. Mogi, A. Kuwabara, A. Damirin, T. Ishizuka, A. Sekiguchi, M. Ishiwara, D.S. Im, K. Sato, M. Muraka- mi, F. Okajima, Role of scavenger receptor class B type I and sphingosine 1-phosphate receptors in high-density lipoprotein-induced inhibition of adhesion molecule expression in endothelial cells, J. Biol. Chem. 281 (2006) 37457-37467.

[25] H.M. Rosenfeldt, J.P. Hobson, M. Maceyka, A. Olivera, V.E. Nava, S. Milstien, S. Spiegel, EDG-1 links the PDGF receptor to Src and focal adhesion kinase activation leading to lamellipodia formation and cell migration, FASEB J. 15 (2001) 2649-2659.

[26] Y. Yatomi, Sphingosine 1-phosphate in vascular biology: possible therapeutic strategies to control vascular diseases, Curr. Pharm. Des. 12 (2006) 575-587.

[27] C. Waeber, N. Blondeau, S. Salomone, Vascular sphingosine-1phosphate $\mathrm{S}_{1} \mathrm{P}_{1}$ and $\mathrm{S}_{1} \mathrm{P}_{3}$ receptors, Drug News Perspect. 17 (2004) 365-382. 